\title{
Gap Junctions Mediate Bystander Cell Death in Developing Retina
}

\author{
Karen Cusato, ${ }^{1}$ Alejandra Bosco, ${ }^{1}$ Renato Rozental, ${ }^{1}$ Cinthya A. Guimarães, ${ }^{2}$ Benjamin E. Reese, ${ }^{3}$ Rafael Linden, ${ }^{2 *}$ and \\ David C. Spray ${ }^{1 *}$ \\ ${ }^{1}$ Department of Neuroscience, Albert Einstein College of Medicine, Bronx, New York 10461, 2Institute of Biophysics, Federal University of Rio de Janeiro, \\ 21949-900, Rio de Janeiro, Brazil, and ${ }^{3}$ Neuroscience Research Institute and Department of Psychology, University of California at Santa Barbara, Santa \\ Barbara, California 93106
}

During development of the retina, programmed cell death helps to establish the final size and distribution of various cell classes in distinct layers of the tissue. Here we show that dying cells in the developing ganglion and inner nuclear layers are clustered spatially and that gap junction inhibitors decrease the clustering of dying cells. To confirm the role of gap junctions in cell death, we induced targeted cell death via intracellular cytochrome $c(\mathrm{Cc})$ and examined the induced cells and their neighbors for apoptotic morphology or caspase-3 cleavage. These studies indicate that bystander killing extends to coupled cells.

Quantitative studies of bystander killing were performed by scrape-loading retinas with $\mathrm{C} c$ in the presence of rhodamine dextran (RD; to identify $\mathrm{C} c$-loaded cells) and by counting pyknotic cells in cryosections. Although only $1.5 \%$ of control scrape-loaded cells (RD alone) showed apoptotic morphology, $97 \%$ of $\mathrm{C} c$ scrape-loaded cells were pyknotic. Moreover, bystander killing extended to neighboring cells, not labeled with RD, and was reduced significantly by the gap junction inhibitors octanol and carbenoxolone. We hypothesize that dying cells in the retina generate a gap junction-permeant apoptotic signal that mediates bystander killing. This novel finding of naturally occurring bystander cell death may have important implications in the histogenesis and pathology of the nervous system.

Key words: retina; cell death; gap junctions; bystander effect; development; inner nuclear layer

\section{Introduction}

Programmed cell death occurs naturally during development of the retina in many species (Perry et al., 1983; Young, 1984; Cook et al., 1998; Georges et al., 1999; Johnson et al., 1999) as well as in degenerative disorders (Chang et al., 1993; Jomary et al., 2001) and retinal traumas (Cook et al., 1995). Although it has been thought that the apoptotic form of programmed cell death occurs at the level of individual cells in tissues (Kerr et al., 1972), including the retina (Cook et al., 1998), clustering of dying cells has been reported (Glucksman, 1951; Gavrieli et al., 1992; Milán et al., 1997), and evidence exists that developmentally regulated apoptosis is induced in groups of cells simultaneously via paracrine signals (Coucouvanis and Martin, 1995; Graham et al., 1996).

Bystander killing, in which the death of one cell propagates to other cells, has been described previously in cells transfected with herpes simplex virus thymidine kinase and treated with ganciclo-

\footnotetext{
Received Dec. 26, 2002; revised May 16, 2003; accepted May 16, 2003.

This work was supported by National Institutes of Health Grants HL 07675 (K.C.), MH65495 (D.C.S.), and EY11087 (B.E.R.); Conselho Nacional de Desenvolvimento Cientifico e Tecnológico (A.B. and R.L.); Fundação de Amparo à Pesquisa do Estado de Rio de Janeiro (R.L.); Pronex-MCT (R.L.); the John Simon Guggenheim Foundation (R.L.); the Kirby Foundation (R.R.); and Alcon Laboratories, Fort Worth, TX (R.R.). We thank José Nilson dos Santos for technical assistance. K.C. and A.B. performed some of these studies at the Instituto de Biofisica Carlos Chagas Filho, Universidade Federal do Rio de Janeiro.

*R.L. and D.C.S. contributed equally to this work.

Correspondence should be addressed to Dr. Karen Cusato, Department of Neuroscience, Albert Einstein College of Medicine, 1300 Morris Park Avenue, Rose F. Kennedy Center 712, Bronx, NY 10461. E-mail: kcusato@aecom.yu.edu.

C. Guimarães's present address: Department of Biological Chemistry, The Hebrew University, Jerusalem, Israel. Copyright $\odot 2003$ Society for Neuroscience $\quad 0270-6474 / 03 / 236413-10 \$ 15.00 / 0$
}

vir (Vile and Hart, 1993; Trosko and Goodman, 1994). This cell death is propagated by gap junction-mediated passage of toxic metabolites (Elshami et al., 1996; Mesnil et al., 1996; Vrionis et al., 1997). Gap junctions are intercellular channels that allow the direct diffusion of small molecules (below $\sim 1 \mathrm{kDa}$ ) (Simpson et al., 1977). Other bystander cell death studies suggest that a natural byproduct of apoptosis itself may pass between coupled cells (Lin et al., 1998). The finding that communication via gap junctions persists during apoptosis in epithelial cell lines (Wilson et al., 2000) and during ischemia in the brain (Lin et al., 1998) allows for the possibility that gap junctions can provide a route for bystander cell killing in ischemia, degenerative diseases, and neural development.

Gap junction proteins are highly expressed in the developing and adult retina (Dermietzel et al., 2000), where they provide electrical and metabolic coupling between both neurons and glia (Vaney, 1991; Penn et al., 1994; Mills and Massey, 1995; Becker et al., 2002). Although the participation of gap junctions in naturally occurring developmentally regulated programmed cell death in the retina has been suggested (Linden, 2000), evidence for such a role is far from conclusive. The present study demonstrates that dying cells in the developing retina are clustered spatially, consistent with bystander cell death, and that the clustering of dying cells during retinal development is decreased by a gap junction-blocking agent, suggesting that the spread of cell death via gap junctions is a mechanism of naturally occurring programmed cell death in the developing nervous system. Further, 
cell death in the retina induced by intracellular delivery of cytochrome $c(\mathrm{Cc})$ led to apoptotic morphology and caspase-3 cleavage in bystander cells. This bystander killing was reduced greatly by inhibitors of gap junction intercellular communication, indicating that gap junctions mediate the spread of cell death. Finally, we show that single-cell injection of $\mathrm{C} c$ and gap junctionpermeant dyes leads to cleavage of caspase- 3 in clusters of coupled cells, indicating that bystander killing occurs in cells coupled via gap junctions. Taken together, these data provide compelling evidence for a role of gap junctions in the spread of cell death in retinal tissue and may provide a mechanistic explanation for the propagation of cell death in injury or disease.

\section{Materials and Methods}

Terminal deoxynucleotidyl transferase-mediated dUTP-biotin nick end labeling assay. C57BL mice, postnatal day 5 (P5) and P8, were killed by decapitation, and the eyes were fixed in $4 \%$ paraformaldehyde (PFA) for $2 \mathrm{hr}$. Retinas were embedded, cryosectioned, and processed for terminal deoxynucleotidyl transferase-mediated dUTP-biotin nick end labeling (TUNEL) labeling (Gavrieli et al., 1992) as previously described (Johnson et al., 1999; Cusato et al., 2001), with the exception that the TUNEL marker was Cy2-streptavidin (1:200, $1 \mathrm{hr}$ at room temperature; Jackson ImmunoResearch, West Grove, PA).

Spatial analysis. P5 and P8 C57BL mice were perfused with PFA; the retinas were flat-mounted, stained with $0.5 \%$ cresyl violet, and dehydrated. Two-dimensional surface reconstructions of positions of pyknotic nuclei in the ganglion cell layer (GCL) and inner nuclear layer (INL) were generated via camera lucida. The drawings were measured on a digitizing tablet (Bioquant Image Analysis, Nashville, TN) or, after scanning, using Scion Image (Scion, Frederick, MD). Nearest neighbor $(\mathrm{NN})$ analysis was performed by measuring the distance from each pyknotic cell in the field to the closest pyknotic cell. Cells closer to the edge of the field than to another cell were excluded, although they might be the closest neighbor to another cell. The frequency distribution of the NN of four fields per retina was plotted. These were compared with NN distributions of randomly generated points of equal density and area by using the Kolmogorov-Smirnov test for cumulative distributions. Random $x, y$ coordinates were generated with Rand software (kindly provided by L. Galli-Resta, Istituto di Neuroscienze, CNR, Pisa, Italy), and their NN distributions were measured. Some P5 animals $(n=3)$ were pretreated with carbenoxolone $\left(20 \mathrm{mg} / \mathrm{kg}\right.$, s.c., in $\mathrm{dH}_{2} \mathrm{O}$; Sigma, St. Louis, $\left.\mathrm{MO}\right)$ and were perfused after $4 \mathrm{hr}$; they underwent spatial analysis of dying cells.

Scrape-loading: dye-coupling experiments. To confirm that the in vivo carbenoxolone treatment decreased gap junctional coupling, we injected P5 animals with carbenoxolone as described above $(n=2)$, or saline $(n=$ 2 ); the animals were decapitated at 2 or $4 \mathrm{hr}$ after the injection. Retinas were removed and flat-mounted GCL up on Millicell-CM inserts (Millipore, Bedford, MA) in Neurobasal medium (Invitrogen, Gaithersburg, $\mathrm{MD}$ ). All liquid was removed, and $10 \mu \mathrm{l}$ of $0.5 \%$ rhodamine dextran (RD; Molecular Probes, Eugene, OR) and 3\% Neurobiotin (NB; Vector Laboratories, Burlingame, $\mathrm{CA}$ ) solution in $100 \mathrm{~mm} \mathrm{KCl}$ was placed on top of the retina. Immediately, the retina was touched with a scalpel, rinsed with medium, and incubated at $37^{\circ} \mathrm{C}$ in $5 \% \mathrm{CO}_{2}$ for $15 \mathrm{~min}$. This scrapeloading procedure is a modification of a previously described transection-loading procedure for studying gap junctional communication (Menezes et al., 2000). Retinas were fixed in PFA for $30 \mathrm{~min}$, rinsed in PBS, placed on filter paper, and sectioned to $150 \mu \mathrm{m}$ on a tissue slicer (Stoelting, Wood Dale, IL). Sections were mounted on coverslips and pretreated with $1 \%$ bovine serum albumin (BSA; Sigma) for $20 \mathrm{~min}$; NB was detected with Cy2-streptavidin (Jackson ImmunoResearch) at a ratio of 1:200 for $1 \mathrm{hr}$. Sections were rinsed, mounted in Fluoromount-G (Fisher Scientific, Pittsburgh, PA), and imaged by confocal microscopy (Olympus Fluoview 500 series, Melville, NY). Quantification was performed on four $z$-series reconstructions per retina ( $z$-step, $1 \mu \mathrm{m} ; 20 \mu \mathrm{m}$ total thickness). Because RD is too large to pass through gap junctions and NB readily passes, RD served as a marker for the cells that were loaded by the scrape-loading procedure, whereas cells single-labeled for NB must have been labeled by the passage of NB from a scrape-loaded cell via gap junctional communication. The number of single-labeled NB cells was quantified as well as the number of cells colocalizing NB and RD. Cells single-labeled for NB were considered to be coupled cells. A "coupling index" was calculated for each field (the number of singlelabeled NB cells divided by the total of NB-labeled cells), giving the proportion of cells labeled via gap junctional communication. Because no differences were observed in the Coupling Index between retinas from 2 or $4 \mathrm{hr}$ conditions, the data were pooled and compared by Student's $t$ test (two-tailed; $p<0.01$ ).

Scrape-loading: bystander killing experiments. Lister hooded rats (P13P15) from our colony at Federal University of Rio de Janeiro were anesthetized and decapitated. Retinas were hemisected and flat-mounted GCL up on Millicell-CM inserts in Neurobasal medium. All liquid was removed, and $10 \mu$ l of either $0.5 \%$ RD or $0.5 \%$ RD plus 1 mм Cc (Sigma) solution in $\mathrm{dH}_{2} \mathrm{O}$ was placed on top of the retina. Immediately, the retina was touched with a scalpel, rinsed with medium, and cultured for $1 \mathrm{hr}$. Finally, retinas were fixed, embedded in gelatin, and cryosectioned at 20 $\mu \mathrm{m}$.

Treatments of the retinal whole mounts included $1 \mathrm{hr}$ preincubation in octanol (100 $\mu \mathrm{M}$; Sigma), S-nitroso-DL-penicillamine (SNAP, $100 \mu \mathrm{M}$; Sigma-RBI), 1 mм 8-Br-cAMP (Calbiochem, San Diego, CA), or 1H$[1,2,4]$ oxadiazolo[4,3a]quinoxalin-1-one (ODQ; $30 \mathrm{~nm}$; Sigma-RBI) in Neurobasal medium. Some animals were injected with carbenoxolone $(20 \mathrm{mg} / \mathrm{kg}$, s.c.), and their retinas were preincubated in carbenoxolone $(10 \mu \mathrm{M})$ for $1 \mathrm{hr}$. Then these retinas were scrape-loaded with $\mathrm{C} c$ and RD or $\mathrm{RD}$ alone, rinsed, and cultured for $1 \mathrm{hr}$ in the same condition of preincubation. Cryosections either were stained with 4,6-diamino-2phenylindole (DAPI; Molecular Probes) or were processed for immunofluorescence with cleaved caspase-3 (1:50, overnight; Cell Signaling Technology, Beverly, MA) and goat anti-rabbit IgG Alexa Fluor 488 (1: 200, 3 hr; Molecular Probes) antibodies.

To demonstrate functional gap junctional coupling and its inhibition in this model, we scrape-loaded retinas with $0.5 \% \mathrm{RD}$ and $3 \% \mathrm{NB}$, as described above, in the presence or absence of carbenoxolone (10 $\mu \mathrm{M})$ and cultured them for $1 \mathrm{hr}$. Carbenoxolone-treated retinas were from animals preinjected as described above. Retinas were cryosectioned, and $\mathrm{NB}$ was visualized with Cy2-streptavidin as described above.

To confirm that RD marked the cells loaded with $\mathrm{C} c$, we scrape-loaded retinas with $\mathrm{RD}$ and $\mathrm{C} c$ conjugated to biotin (biotin- $\mathrm{C} c$ ). Biotin- $\mathrm{C} c$ was prepared by following the kit manufacturer's instructions (Molecular Probes) and was dialyzed to remove excess free biotin. Retinas were fixed in PFA, and cryosectioned to $20 \mu \mathrm{m}$. Biotin-Cc was visualized with Cy2streptavidin at a ratio of 1:250 for $1 \mathrm{hr}$.

Analysis. Dying cells were quantified on the basis of pyknotic morphology in cryosections of scrape-loaded and DAPI-stained tissue (400X magnification, oil immersion objective). Data were collected from the GCL and INL and combined. Six to eight fields per retina, $175 \mu \mathrm{m}$ long each, were analyzed in three retinas per condition, unless otherwise stated. All fields were from nonadjacent sections. For controls scrapeloaded with RD in the presence of gap junction inhibitors and for the octanol experiments, eight fields from a single retina per condition were quantified in each case. In Neurobiotin dye-coupling experiments eight fields from two carbenoxolone-treated retinas and two control retinas were analyzed. Retinas were imaged by confocal microscopy, and digital images of $z$-series reconstructions were processed with Adobe Photoshop software (Mountain View, CA).

Single-cell injections. For single-cell injections Long-Evans rats, the strain from which Lister hooded rats were derived and the most closely related strain available in the USA, were purchased from Charles River Laboratories (Wilmington, MA). Retinas from P13-P21 rats were dissected in oxygenated Locke's solution [containing (in $\mathrm{mM}$ ) $112.5 \mathrm{NaCl}$, $20 \mathrm{NaHCO}_{3}, 3.6 \mathrm{KCl}, 1.2 \mathrm{CaCl}_{2}, 2.4 \mathrm{MgCl}_{2}, 10$ glucose, and $10 \mathrm{HEPES}$, $\mathrm{pH}$ 7.3] and flat-mounted vitreal side up on nitrocellulose paper (Millipore) with a $5 \mathrm{~mm}$ hole. Single cells were impaled with a high-resistance microelectrode, and Alexa Fluor 488 (AF488, 1 mm; Molecular Probes) was injected by using brief overcompensation of the negative capacitance control (World Precision Instruments, Sarasota, FL). AF488 was injected alone or coinjected with $1 \mathrm{~mm} \mathrm{Cc}$ (in $150 \mathrm{~mm} \mathrm{NaCl}$ ) on a Nikon Eclipse $600 \mathrm{FN}$ microscope equipped with xenon arc lamp illumination and mi- 

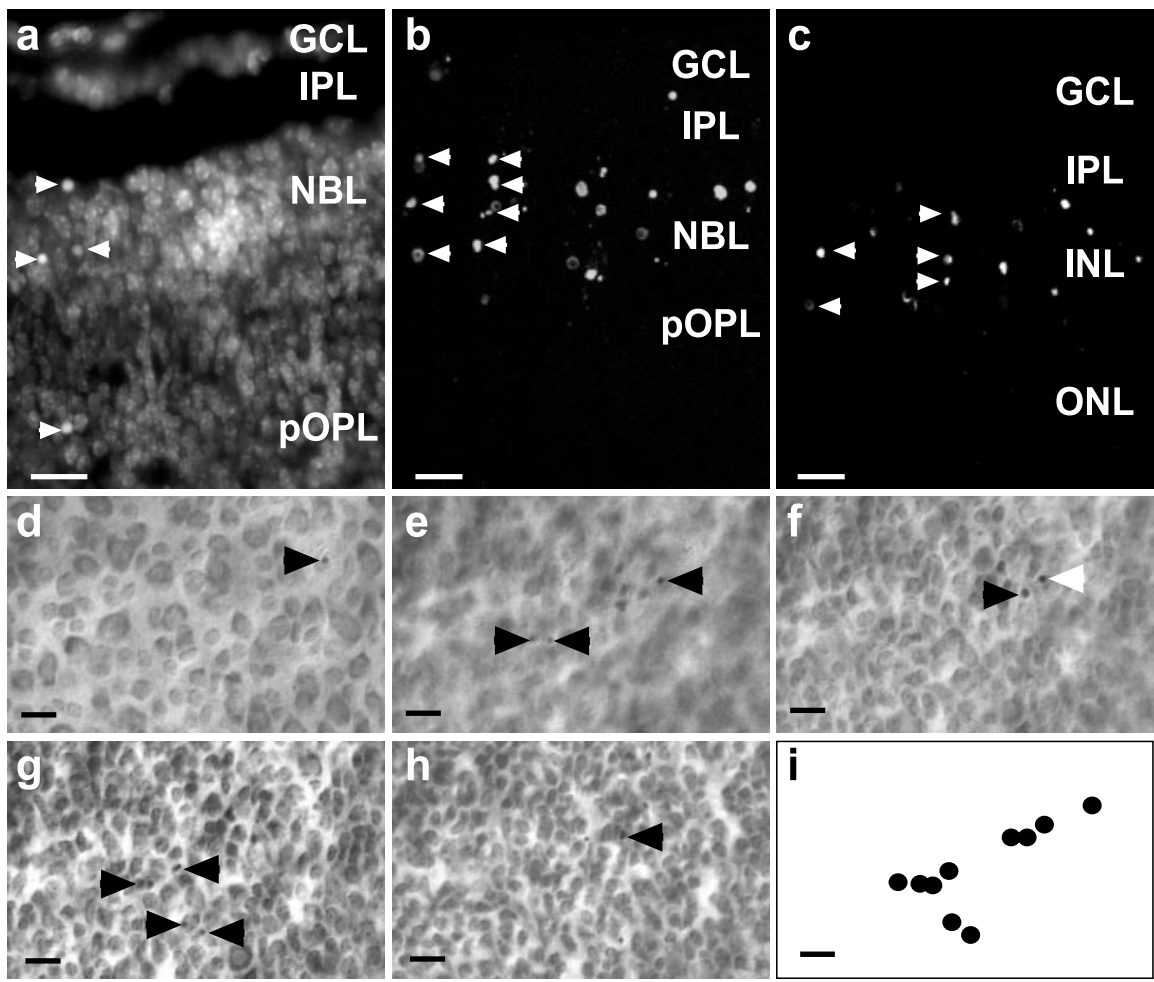

j

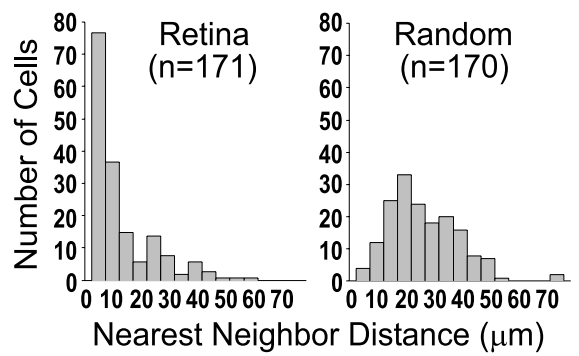

k

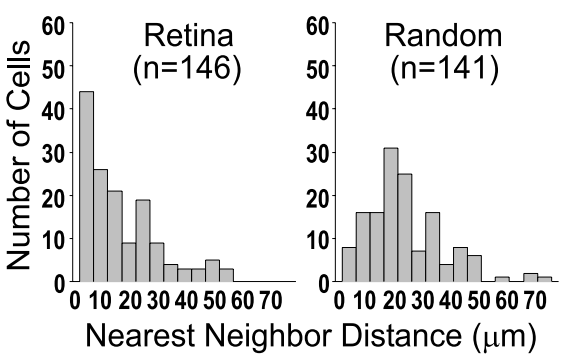

Figure 1. Spatial analysis of dying cells in the developing retina revealed a clustered distribution. a, Dying cells (arrowheads) evidenced by nuclear condensation (pyknosis) in DAPI-stained radial sections ( $20 \mu \mathrm{m})$ of P5 mouse retina. Z-series projections (15 $\mu \mathrm{m}$ ) of TUNEL-labeled P5 (b) and P8 (c) mouse retina show that clusters of dying cells are frequent in developing retina. Scale bars in $a-c, 10 \mu \mathrm{m}$. GCL, Ganglion cell layer; INL, inner nuclear cell layer; IPL, inner plexiform layer; NBL, neuroblastic layer; ONL, outer nuclear layer; OPL, outer plexiform layer; pOPL, presumptive OPL. $d-i$, Single field from a P5 mouse retina stained with cresyl violet, whole-mounted, and observed at different focal planes. Arrowheads point to pyknotic cells, and the white arrowhead indicates a pyknotic nucleus visible in multiple planes. $d$, Ganglion cell layer. $e$, Inner plexiform layer. $f, g$, Inner portion and outer portion $(h)$ of inner nuclear layer. $i$, A two-dimensional surface reconstruction of the positions of the dying cells throughout the $\mathrm{GCL}$ and INL denotes the tendency of the dying cells to be clustered. Scale bar, $d-i, 20 \mu \mathrm{m}$. $j$, Nearest neighbor (NN) distributions of P5 mouse retina (left) and of random points in fields of equal size and density (right). $k$, NN distribution of P8 mouse retina (left) and NN distribution of random points in fields of equal size and density (right). At both ages more dying cells are located near to one another in the retinas than in the random fields. All retinal NN distributions were significantly different from the associated random field NN distributions (Kolmogorov-Smirnov test, $p<0.001$ ).

cromanipulators (PCS-PS60, Burleigh, McHenry, IL). Some injections were made in the presence of $75 \mu \mathrm{M}$ carbenoxolone. During injection or afterward the injected cells were photographed (Coolpix 950, Nikon). Retinas subsequently were cultured at $37^{\circ} \mathrm{C}$ in $5 \% \mathrm{CO}_{2}$ for $1 \mathrm{hr}$, fixed in PFA for $30 \mathrm{~min}$, and rinsed in PBS. Finally, retinas were processed for immunofluorescence with CM1 (1:5000; kindly provided by Dr. Anu Srinivasan, IDUN Pharmaceuticals, San Diego, CA) or cleaved caspase-3 (1:50) for $3 \mathrm{~d}$ (both antibodies recognize the cleaved form of caspase-3), followed by goat anti-rabbit IgG Alexa Fluor 594 (1:200 for $3 \mathrm{hr}$ ). Retinas were mounted in Vectashield (Vector Laboratories) and photographed (Spot camera, Morrell Instruments, Melville, NY).

All animals were treated, maintained, and killed in accordance with Society for Neuroscience resolutions on the use of animals in research and National Institutes of Health guidelines as well as institutional protocols.

\section{Results}

Distribution of dying cells in

developing retina

When cryosections of developing mouse retina were labeled with DAPI, pyknotic cells were evident and often were observed to be in columns (Fig. $1 a$, arrowheads). In a single plane of focus often just a few dying cells were observed, but they were usually near one another. In TUNEL-labeled sections from P5 mouse retina the dying cells were found in both the ganglion cell layer (GCL) and the inner nuclear layer (INL), sometimes spanning the INL in columns. As in DAPI-stained tissue, a single plane of focus revealed some dying cells, usually clustered. However, $z$-series reconstructions ( $15 \mu \mathrm{m}$ thick) from confocal images of TUNEL-labeled sections of P5 and P8 mouse retina showed that, within a few micrometers of retinal thickness, many dying cells were present, and multiple columns were visible (Fig. $1 b, c$, arrowheads). Given that the estimated clearance time of apoptotic cells in the developing retina is on the order of $1 \mathrm{hr}$ or less (Perry et al., 1983; Voyvodic et al., 1995), the presence of groups of dying cells suggests that the cells have undergone death simultaneously or within a relatively short period of time, indicating that cell death does not necessarily operate at the level of individual cells.

\section{Nearest neighbor distributions}

To confirm that dying cells are clustered in the developing retina, we performed $\mathrm{NN}$ analysis (Wässle and Reimann, 1978) on P5 and P8 retinal whole mounts stained with cresyl violet. Pyknotic cells were found at different focal planes through the thickness of the GCL and INL (Fig. $1 d-h$, arrowheads), and, when their relative positions were plotted in two dimensions, a clustered distribution was evident (Fig. 1i). Fields of random $x, y$ coordinates of equal size and density were generated, and their $\mathrm{NN}$ distribution was determined also. Figure $1, j$ and $k$, shows representative NN distributions from single P5 and P8 retinas, respectively. NN distributions of dying cells from P5 mouse retina show that, on average ( $n=3), 64 \%$ of pyknotic cells have a NN distance of $<15$ $\mu \mathrm{m}$, whereas in random distributions only $23 \%$ of the NN distances were $<15 \mu \mathrm{m}$. In P8 mouse retina, on average $(n=2)$, $69 \%$ of pyknotic cells had NN distances of $<15 \mu \mathrm{m}$, whereas $29 \%$ of the NN distances were $<15 \mu \mathrm{m}$ in random distributions. All retinas were significantly different from the associated random distributions (one-tailed Kolmogorov-Smirnov test, $p<0.001$ ), clearly showing that the distribution of dying cells in the developing retina is clustered. 
There are a number of developmental events that may account for a clustered distribution of dying cells in the retina, including paracrine release of diffusible survival-promoting molecules, release of diffusible death-inducing molecules, and intercellular transport of death-inducing substances via gap junctions. Many types of retinal cells are coupled by gap junctions in adulthood (Raviola and Raviola, 1982; McMahon et al., 1989; Vaney, 1991; Mills and Massey, 1995; De Vries et al., 2002) and during development (Penn et al., 1994; Becker et al., 2002). We have tested the hypothesis that gap junction-mediated cell-cell signaling plays a role in the clustering of dying cells by treating P5 mice in vivo with carbenoxolone $(20 \mathrm{mg} / \mathrm{kg}$, s.c.), a gap junction inhibitor (Davidson and Baumgarten, 1988). To determine that our carbenoxolone injection regimen decreased gap junctional communication in the developing retina, we have used a modification of the well established scrape-loading dye-transfer technique, which interrupts the membranes of multiple cells simultaneously, allowing the passage of water-soluble dyes (El-Fouly et al., 1987; De Pina-Benabou et al., 2001). In this case we have removed the retinas 2 or $4 \mathrm{hr}$ after subcutaneous carbenoxolone injection, scrape-loaded them with a solution containing $0.5 \% \mathrm{RD}(70$ $\mathrm{kDa})$ and $3 \% \mathrm{NB}(286 \mathrm{D})$, and allowed the NB to diffuse for 15 min before fixation. Because RD is too large to pass through gap junctions and therefore is retained in the scrape-loaded cells but NB is gap-junction permeable (Kita and Armstrong, 1991; Vaney, 1991), gap junctional coupling is evidenced by cells that are labeled with Neurobiotin but lack RD (Becker et al., 2002).

Gap junctional coupling was evidenced by NB transfer from $\mathrm{RD}$-containing scrape-loaded cells in vehicle-injected animals (Fig. 2a,b, arrowheads); however, the intercellular spread of NB was decreased in retinas from carbenoxolone-injected animals (Fig. $2 c, d$, arrowheads). In controls, the inner plexiform layer (IPL) contained many NB-labeled cell processes (Fig. $2 b$, double arrowheads), whereas in carbenoxolone-treated animals the labeling in the IPL was reduced (Fig. $2 d$, double arrowheads). However, horizontal cell processes in the presumptive OPL (pOPL) were labeled strongly for NB (Fig. $2 d$, double arrowheads), indicating that the decreased labeling in the IPL was attributable to a reduced number of processes labeled in the IPL. Quantification of dye coupling showed that the proportion of all NB-labeled cells that were single-labeled (the Coupling Index) was decreased significantly in carbenoxolone-treated animals (Fig. $2 e ; p<0.01$, two-tailed $t$ test). When NN distributions from $\mathrm{P} 5$ mice $(n=3)$ treated in vivo with carbenoxolone were compared with untreated P5 mice $(n=3)$, the percentage of dying cells with a NN distance of $<15 \mu \mathrm{m}$ was decreased significantly from 64 to $30.3 \%$, suggesting that the clustering of dying cells is mediated by gap junctions (Fig. $2 f ; p<0.01$, two-tailed $t$ test with correction for unequal variance). The fact that the proportion of cells labeled via coupling and the percentage of dying cells with a NN distance $<15 \mu$ m were reduced by carbenoxolone to a remarkably similar degree (compare Fig. 2e,f) suggests that the decrease in coupling accounts for the decrease in the clustering of dying cells.

\section{Induction of bystander killing}

If a spread of cell death signals occurs, then induction of cell death in targeted cells should lead to cell death in other "bystander" cells. Because such studies require the absence of naturally occurring cell death, we have used rat retinas (which make exceptional in vitro preparations) from $\mathrm{P} 13-\mathrm{P} 15$ animals, a time at which the majority of developmental cell death already has occurred (Horsburgh and Sefton, 1987). To test the hypothesis that dying cells induce bystander cell death, we have used the modified scrape- loading technique to introduce $\mathrm{C} c$ into the cytoplasm of retinal cells in situ. Scrape-loading not only is used to study gap junctional coupling, but also has been shown to be an effective method for loading multiple cells simultaneously with functional proteins (McNeil et al., 1984; Ortiz et al., 1987; Morris et al., 1989; Linseman et al., 2001). Cc release from the mitochondria during apoptosis (Liu et al., 1996) activates caspase-9, which then activates important effectors of cell death including caspase-3 (P. Li et al., 1997). Because RD (70 kDa) and Cc (12.6 kDa) are both too large to pass through gap junctions, they are confined to the cells that have had their membranes permeabilized by the scrapeloading procedure; thus RD labeling should serve as an indicator of which cells were lesioned by the procedure so that the fate of the $\mathrm{C} c$-loaded cells could be followed. To confirm this, we scrapeloaded retinas with $\mathrm{RD}$ and $\mathrm{Cc}$ that is conjugated to biotin (biotin- $\mathrm{C}$; Fig. $3 a-c$ ). Both $\mathrm{RD}$ and biotin-Cc were found in many cell types in the GCL and INL near the lesion (asterisks). RD and biotin-Cc showed a high degree of colocalization with near total overlap, not only in the somata but in the processes as well (Fig. $3 c$, double arrowheads). Rarely were cells labeled for biotin-Cc alone (Fig. 3b,c, arrowhead), indicating that RD efficiently identified the population of cells loaded with $\mathrm{C} c$.

Scrape-loading with RD and $\mathrm{C} c$ induced caspase- 3 cleavage both in RD-labeled cells and in bystander cells as evidenced by immunolabeling with an antibody that recognizes only the cleaved form of caspase-3 (Fig. $3 d-f$ ), which is the active protease (Nicholson et al., 1995; P. Li et al., 1997). This finding indicates that both primary and bystander cell death is caspase-mediated. Often cell processes were labeled, indicating that cleaved caspase- 3 was located throughout the cytoplasm (Fig. $3 e$, double arrowheads). Scrape-loading with $\mathrm{RD}$ alone rarely induced caspase- 3 cleavage in RD-labeled cells, and only occasional immunolabeled cells were observed (Fig. $3 g-i$ ). Scrape-loading with $\mathrm{C} c$ induced morphological features of cell death as evidenced by pyknotic nuclei in DAPI-stained tissue (Fig. $4 a, b$ ) in both RDlabeled cells (arrows) and in cells not loaded with $\mathrm{C} c$ and RD (Fig. $4 a, b$, arrowheads). Horizontal cells often were labeled with RD; however, their nuclei were rarely pyknotic (Fig. $4 a, b$, double arrowheads), indicating that they were resistant to $\mathrm{C} c$-induced cell death. RD alone rarely induced pyknosis in labeled cells (Fig. $4 c, d$, arrow). Whereas only $1 \%$ of cells scrape-loaded with RD showed apoptotic morphology, 97\% of cells scrape-loaded with RD and $\mathrm{C} c$ were pyknotic $1 \mathrm{hr}$ after scrape loading (Fig. $4 e$ ), consistent with a previous study showing induced cell death in $95 \%$ of cells after pressure injection of Cc in cell lines (Brustugun et al., 1998).

\section{Inhibition of bystander killing}

A "bystander index" was calculated by dividing the number of pyknotic cells not labeled with RD (bystander cells) by the total number of pyknotic cells for each field. In the presence of $\mathrm{C} c$, the Bystander Index was $0.66 \pm 0.02$ (mean \pm SEM), showing that two of three dying cells are bystanders (Fig. 4f). To determine whether bystander cell killing was mediated via gap junction intercellular communication, we scrape-loaded retinas with $\mathrm{C} c$ and $\mathrm{RD}$ in the presence of agents that decrease gap junctional communication: $10 \mu \mathrm{M}$ carbenoxolone (Davidson and Baumgarten, 1988 ) and $100 \mu \mathrm{M}$ octanol (Spray et al., 1986). In carbenoxolone treatments the animals were injected $\left(20 \mathrm{mg} / \mathrm{kg}\right.$, s.c., in $\left.\mathrm{dH}_{2} \mathrm{O}\right) 1$ $\mathrm{hr}$ before death, as described above. This combined injection and in vitro incubation protocol has been shown previously to reduce dye coupling in the forebrain of rats (Menezes et al., 2000). Both of these agents significantly decreased bystander cell death (Fig. $4 f$ ). 

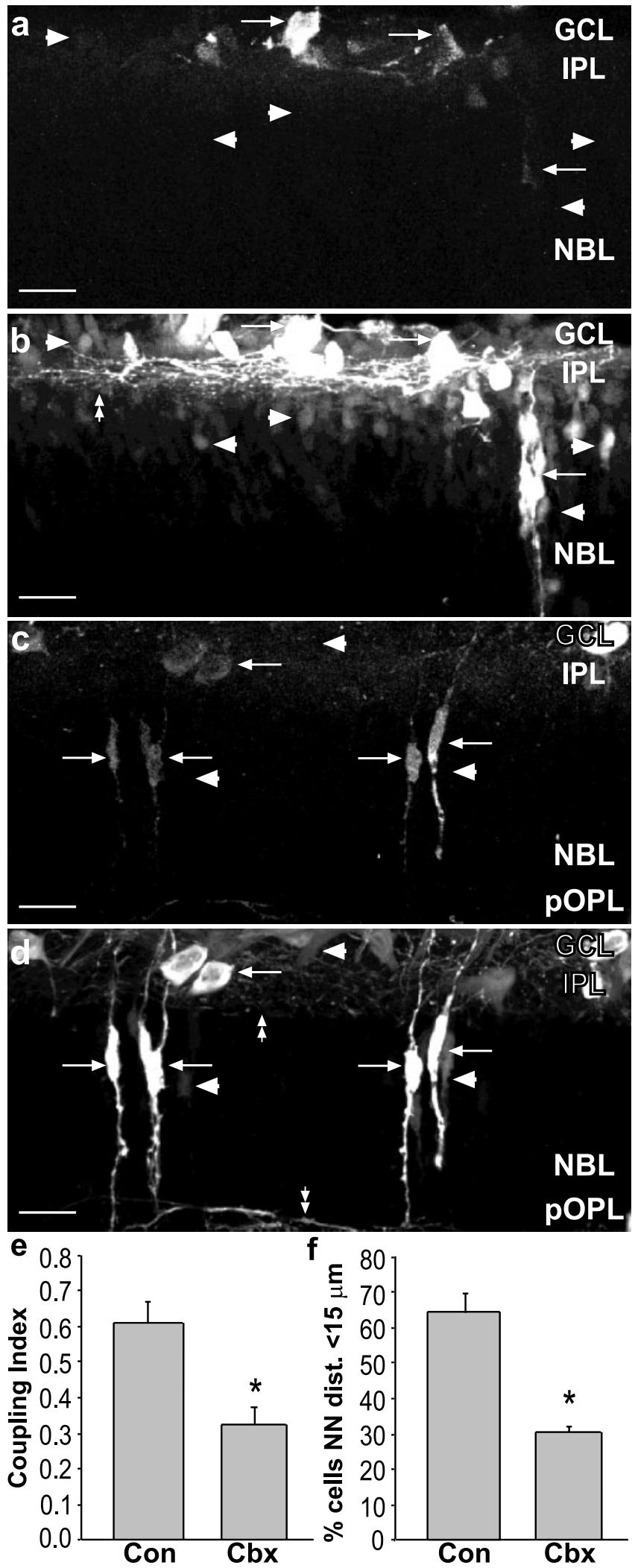

Figure 2. Carbenoxolone treatment decreased dye coupling and clustering of dying cells in vivo. $a, b, Z$-series projection $(20 \mu \mathrm{m})$ of retinal sections from P5 mouse injected with vehicle and scrape-loaded with RD and NB. $a$, RD labels cells in GCL and NBL (arrows). b, NB (Cy2streptavidin) is localized in cells that were scrape-loaded with RD (arrows) and other cells not loaded with RD (arrowheads). Many processes in the IPL were labeled with NB (double arrowhead). Arrowheads in $a$ indicate position of coupled cells in $b . c, d$, Carbenoxolone treatment decreases spread of NB. C, RD labeling (arrows) of scrape-loaded retina from treated animal (20 $\mathrm{mg} / \mathrm{kg}$, s.c.). $d$, NB labeling of same field shows few NB-labeled cells that do not colocalize with
Because carbenoxolone may exert its actions via inhibition of cAMP and cGMP phosphodiesterases (Vapaatalo et al., 1978), the role of these molecules in the bystander effect was determined. cAMP and cGMP have been shown to decrease coupling in the retina, cAMP directly and cGMP via nitric oxide (NO) stimulation (Mills and Massey, 1995). The addition of $1 \mathrm{~mm}$ 8-Br-cAMP and $100 \mu \mathrm{M}$ SNAP, a NO generator (Singh et al., 1996), also significantly decreased the bystander effect (Fig. $4 f$ ). Further, the rescue by carbenoxolone was reversed partially by the addition of $30 \mathrm{~nm}$ ODQ, a potent inhibitor of soluble guanylyl cyclase (Moro et al., 1996), further indicating a role for cGMP in the blockage of bystander cell death. None of these agents changed the percentage of RD-labeled cells killed by the scrapeloading procedure (Fig. 4e), indicating that the rescue was specific for bystander cells. NO has been shown to bind caspases reversibly by $S$-nitrosylation (J. Li et al., 1997). However, the finding that $100 \mu \mathrm{M}$ SNAP decreased the bystander killing without decreasing the death of RD-labeled cells indicates that this concentration of SNAP is exerting its effects via a different mechanism, potentially via the inhibition of gap junctions.

\section{Dye coupling}

To confirm that cells are coupled in our in vitro model, we scrapeloaded the retina with $\mathrm{RD}$ and NB. Cy2-conjugated streptavidin revealed intercellular spread of NB in cells in the GCL and INL (Fig. 5a,b), whereas carbenoxolone treatment (the same protocol described above for bystander death studies) decreased coupling (Fig. $5 c, d$ ). As in previous dye-coupling experiments, the number of cells labeled with NB alone was divided by the total number of labeled cells to generate a Coupling Index (comparable to the Bystander Killing Index), which was reduced significantly by carbenoxolone (Fig. $5 e$ ) from $0.63 \pm 0.07$ to $0.24 \pm 0.03$ (two-tailed $t$ test, $p<0.01)$. This decrease in Coupling Index by carbenoxolone coincides well with the decrease in Bystander Killing Index by carbenoxolone $(0.66 \pm 0.02$ to $0.19 \pm 0.02$; Fig. $4 f)$.

\section{Single-cell injections}

To induce bystander cell death and confirm that dying cells are coupled via gap junctions, we coinjected single cells in the ganglion cell layer of live, whole-mounted rat retina (P13-P21) with $1 \mathrm{~mm}$ Alexa Fluor 488 (AF488), a gap junction-permeable dye, and $1 \mathrm{~mm} \mathrm{C}$, which is too large $(12.6 \mathrm{kDa})$ to pass through gap junction channels. Control injections of AF488 alone and injections of AF488 and $\mathrm{C} c$ showed that similar numbers of cells were coupled to at least one other cell ( $45 \pm 5.4 \% ; n=48$ injected cells in 4 retinas for AF488 alone vs $47 \pm 4.8 \% ; n=32$ cells from 4 retinas for $\mathrm{AF} 488$ and $\mathrm{Cc}$ ), indicating that dye spread is not decreased by $\mathrm{C} c$ injection. To confirm that dye spread was the result of gap junctional coupling, we performed injections in the presence of $75 \mu \mathrm{M}$ carbenoxolone, which decreased coupling to at least one other cell by $66 \%(15.4 \pm 3.8 \% ; n=33$ cells from 3 retinas). This concentration of carbenoxolone was used in an attempt to increase the efficacy of gap junction blockade over that obtained in previous experiments and previously has been shown to decrease dye coupling in other cell types (Rozental et al., 2001).

In other retinas the bystander cell death was quantified after

RD (arrowheads). Processes in IPL and pOPL are indicated by double arrowheads. Scale bars in $a-d, 20$ $\mu \mathrm{m} . e^{e}$, Coupling Index for control (Con) and carbenoxolone (Cbx) indicates a significant decrease in dye coupling by Cbx treatment (asterisks indicate groups significantly different from controls; Student's $t$ test, $p<0.01)$. $f$, Cbx reduces the percentage of dying cells with a NN distance shorter than $15 \mu \mathrm{m}$ in a manner that closely parallels the decrease in the Coupling Index. 


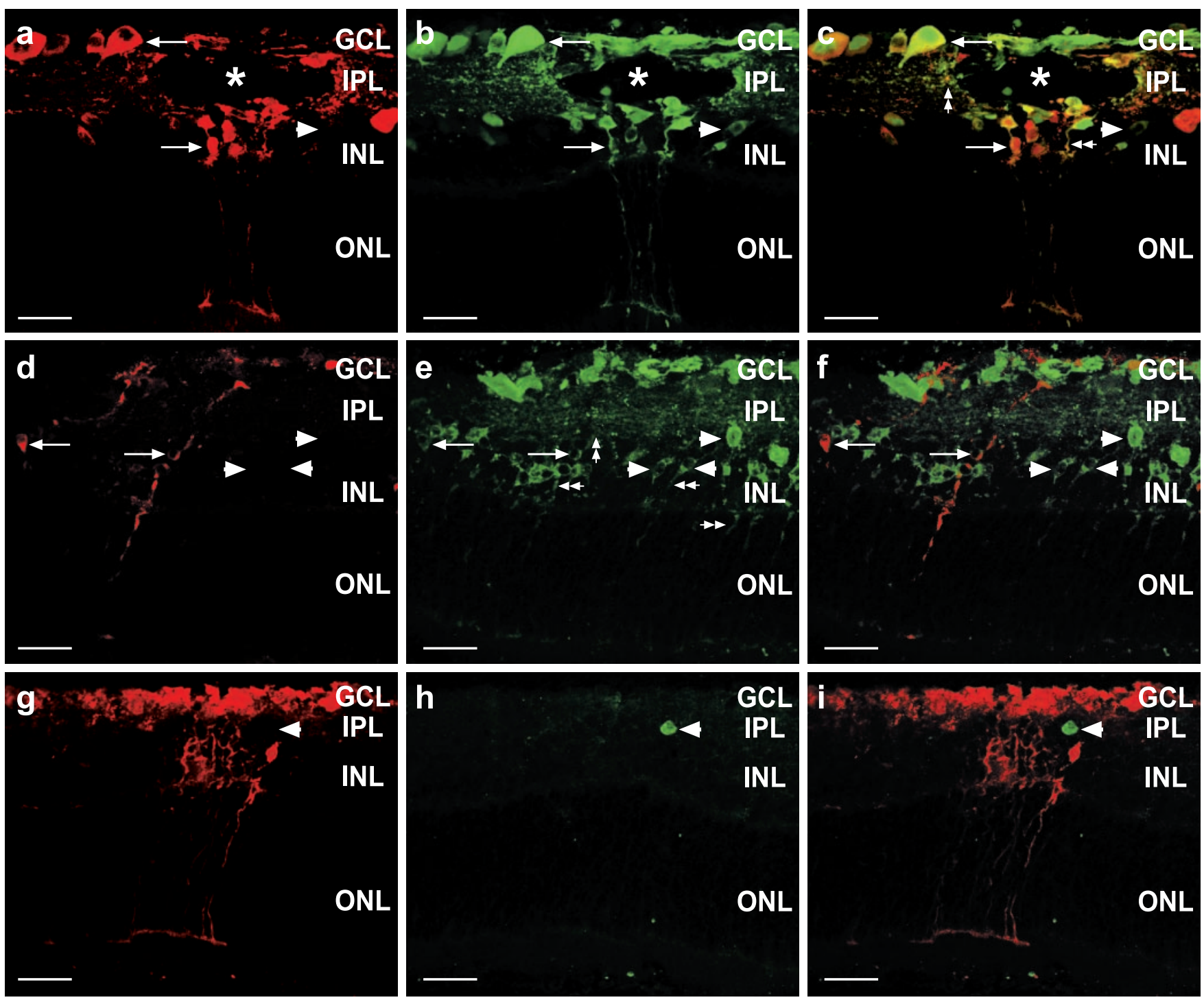

Figure 3. Targeted killing of primary cells induced bystander cell death in vitro. $a-i$, Confocal images of radial sections $(20 \mu \mathrm{m})$ from P13-P15 rat retinas scrape-loaded with or without Cc in the presence of RD-dextran. $a-c$, Retina scrape-loaded with RD and biotin-Cc. The asterisks denote the shallow scrape-loading incision spanning the GCL and IPL in part of thez-series. Shown are RD (red, a), biotin-Cc (Cy2-streptavidin; green, b), and the merged image ( $c$ ). RD and Cc are both too large to pass through gap junctions and thus remain confined to the scrape-loaded cells. Both somata (arrows) and processes (double arrowheads) are labeled. RD and Cc colocalize (c) with only occasional cells labeled for (c alone (arrowhead); therefore, RD clearly identifies the cells loaded with Cc. $d-f$, Retina scrape-loaded with RD and (c, immunolabeled for cleaved caspase-3.d, RD-labeled cells (red; arrows) were immunopositive (e) for cleaved caspase-3 (green; arrows). Cells not labeled with RD also were labeled for cleaved caspase- 3 (arrowheads), indicating bystander cell death. Cleaved caspase- 3 was detected in both somata and processes (double arrowheads). $f$, Merged image indicates that RD and cleaved caspase were colocalized (arrows) in some cells, but other dying cells did not contain RD (arrowheads). $g$-i, Control retina scrape-loaded with RD alone. $g$, RD-labeled cells (red) were not labeled for cleaved caspase-3 $(h)$. However, one cell not labeled with RD was dying $(h$, $i$; arrowhead). This indicates that neither the scrape-loading nor the RD was a potent inducer of cell death. $i$, Merged image. Scale bars in $a-i, 20 \mu \mathrm{m}$.

control and $\mathrm{Cc}$ injections. After multiple injections the retinas were maintained in vitro for $1 \mathrm{hr}$ after the last cell was injected, fixed, and immunolabeled for cleaved caspase-3. Quantification was limited to cells that showed dye-spread, and data were pooled from multiple retinas. Bystander death was considered to have occurred if multiple apoptotic cells were found within a cluster of AF488-labeled cells (Fig. $6 a-d$ ). Cc induced cell death in $60.5 \%$ of injected cells (26 of 43 cells from 9 retinas), whereas only one cleaved caspase-3-labeled cell was seen in control injections of AF488 alone ( 1 of 16 cells from 4 retinas). In AF488-labeled clusters containing at least one dying cell, death spread from primary to at least one bystander cell in $57.6 \%$ of cases ( 15 of 26 cells from 9 retinas) as determined by immunolabeling for cleaved caspase-3 (Fig. 3b). Spread of cell death was seen in only one case in the presence of carbenoxolone $(4 \% ; n=25$ cells from 3 retinas), a treatment that reduced coupling of the injected cells to other cells to $8 \%$ in this series of injections. Occasional dying cells were seen in the GCL of control retinas (Fig. $6 e, f$ ), indicating that the lack of labeling was attributable to failure to induce caspase cleavage in control injections rather than failure to immunolabel cleaved caspase-3. Likewise, the fact that many injections (both control and $\mathrm{Cc}$ ) did not lead to caspase-3-immunopositive cells indicates that the labeling pattern was not the result of fluorescence bleedthrough in instances when bystander death was observed.

Control injections of biotin-Cc and AF488 showed that only single cells were labeled with Cc despite spread of AF488 to other nearby cells (data not shown), indicating that $\mathrm{C} c$ did not enter 

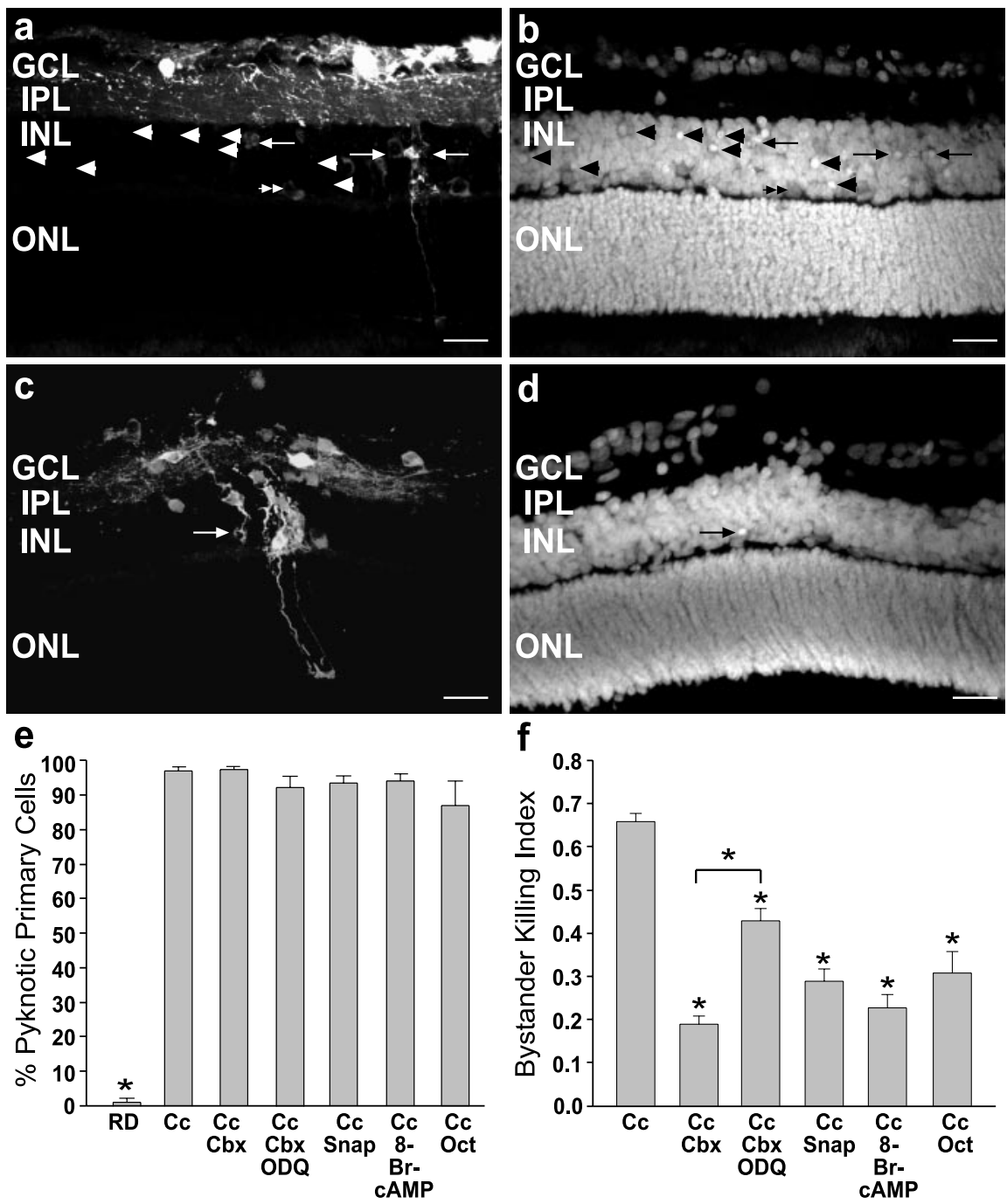

Figure 4. The propagation of cell death was decreased by the inhibition of gap junction coupling in vitro. $a, b$, Radial sections of P13 rat retina scrape-loaded with $\mathrm{RD}$ and $(c$. RD labeling $(a)$ identified the primary cells loaded with $(c$, and DAPI staining $(b)$ showed pyknotic nuclei in cells labeled with RD (arrows) and also in many bystander cells unlabeled with RD (arrowheads). Note in $a$ and $b$ that the RD-loaded horizontal cells (double arrowheads) were not pyknotic. $c, d$, Retina scrape-loaded with RD alone. $c$, RD-labeled cells were occasionally pyknotic (arrow) in DAPI staining $(d)$ of the same field. Scale bars in $a-d, 20 \mu$ m. $e$, Percentage of scrape-loaded cells killed for control (RD), $C c$, and C $c$ with drug treatments. RD was significantly different from $C c(p<0.01$; one-way ANOVA, Duncan's multiple range test), but treatment with gap junction inhibitors did not decrease the death of cells loaded with C. $f$, The Bystander Killing Index for retinas treated with Cc demonstrates that gap junction inhibitors (carbenoxolone and octanol) as well as CAMP and NO generators (SNAP) decreased the bystander killing effect significantly when compared with C $c$ alone (asterisks indicate significant differences from $C c ; p<0.01$; one-way ANOVA, Duncan's multiple range test). ODQ significantly attenuated the effects of carbenoxolone, indicating a role for cGMP as well. None of these agents decreased cell death in primary cells $(e)$, indicating that the rescue effect was specific for the bystander cells. Cc, Cytochrome c; Cbx, carbenoxolone; ODQ, 1H-[1,2,4] oxadiazolo[4,3a]quinoxalin-1-one; SNAP, S-nitroso-DL-penicillamine; 0ct, octanol.

cells other than the injected cell and thereby ruling out an extracellular route for the bystander cell killing.

\section{Discussion}

The fundamental findings of this study are that dying cells are clustered in the normal, developing retina (Fig. 1), that this clustered cell death is reduced by a gap junction inhibitor (Fig. 2), that bystander cell death may be induced by targeted deletion of cells (Figs. 3, 4, 6), and that the propagation of cell death is decreased by inhibition of gap junction coupling in vitro (Figs. 4, 5). These findings lead to the conclusion that bystander killing via gap junctions contributes to cell death in the normal develop- ing nervous system, supporting the hypothesized role of this novel mechanism (Linden, 2000).

The data from both the distribution of TUNEL-labeled cells and the NN analysis in the mouse (Fig. 1) suggest that the probability of cells dying together is greater than the probability of dying singly. The reduction of the number of cells that die within short distances of other dying cells by carbenoxolone, in conjunction with the decrease in dye-coupling, suggests that gap junctions mediate the clustering of dying cells (Fig. 2).

We also demonstrate bystander killing by scrape-loading retinas with $\mathrm{C} c$ (Figs. $3 d-f, 4 a, b, f)$. At P13 the bulk of cell death in the rat retina already has occurred, and few pyknotic cells are found (Horsburgh and Sefton, 1987). The occasional dying cells found in control retinas in this study (Figs. $3 g-i, 4 c, d, f$ ) were infrequent enough to suggest that they may be the result of naturally occurring cell death rather than induced cell death.

One possible mechanism by which cell death may be propagated is via the transfer of cytotoxic metabolites from dying cells to other cells via gap junctions. Recent evidence has shown that gap junctions remain open during apoptosis (Lin et al., 1998; Wilson et al., 2000), and gap junctionmediated bystander effects previously have been shown in cell lines (Mesnil et al., 1996; Vrionis et al., 1997; Lin et al., 1998). The bystander effect induced by $\mathrm{C} c$ was decreased by preinjection of $20 \mathrm{mg} / \mathrm{kg}$ carbenoxolone and preincubation of the retina in $10 \mu \mathrm{M}$ carbenoxolone (Fig. 4f). Carbenoxolone is a gap junction inhibitor (Davidson and Baumgarten, 1988) but has other known functions, including effects on steroid metabolism in the eye (Rauz et al., 2001). This same protocol significantly decreased dye coupling in retinas scrapeloaded with RD and NB (Fig. $5 c-e$ ), and the reduction in coupling was comparable to the decrease in bystander killing, further evidence that the effect was mediated by carbenoxolone-induced inhibition of gap junctional coupling rather than nonspecific carbenoxolone effects. NO, octanol, and a cAMP analog also decreased the bystander effect (Fig. $4 f$ ). Each of these agents has multiple actions, but all have been shown to inhibit cell coupling in the retina (McMahon et al., 1989; Mills and Massey, 1995). Taken together, these results indicate that gap junctional coupling is involved in the propagation of cell death in the retina.

Single-cell injections of $\mathrm{C} c$ and AF488 directly showed that bystander killing is mediated by the activation of caspase-3 (Fig. $6 a-d)$. Incubation of retinas in $75 \mu \mathrm{M}$ carbenoxolone decreased both the dye coupling and propagation of cell death. Because $\mathrm{C} c$ is too large to pass through gap junctions, it is likely that a byprod- 

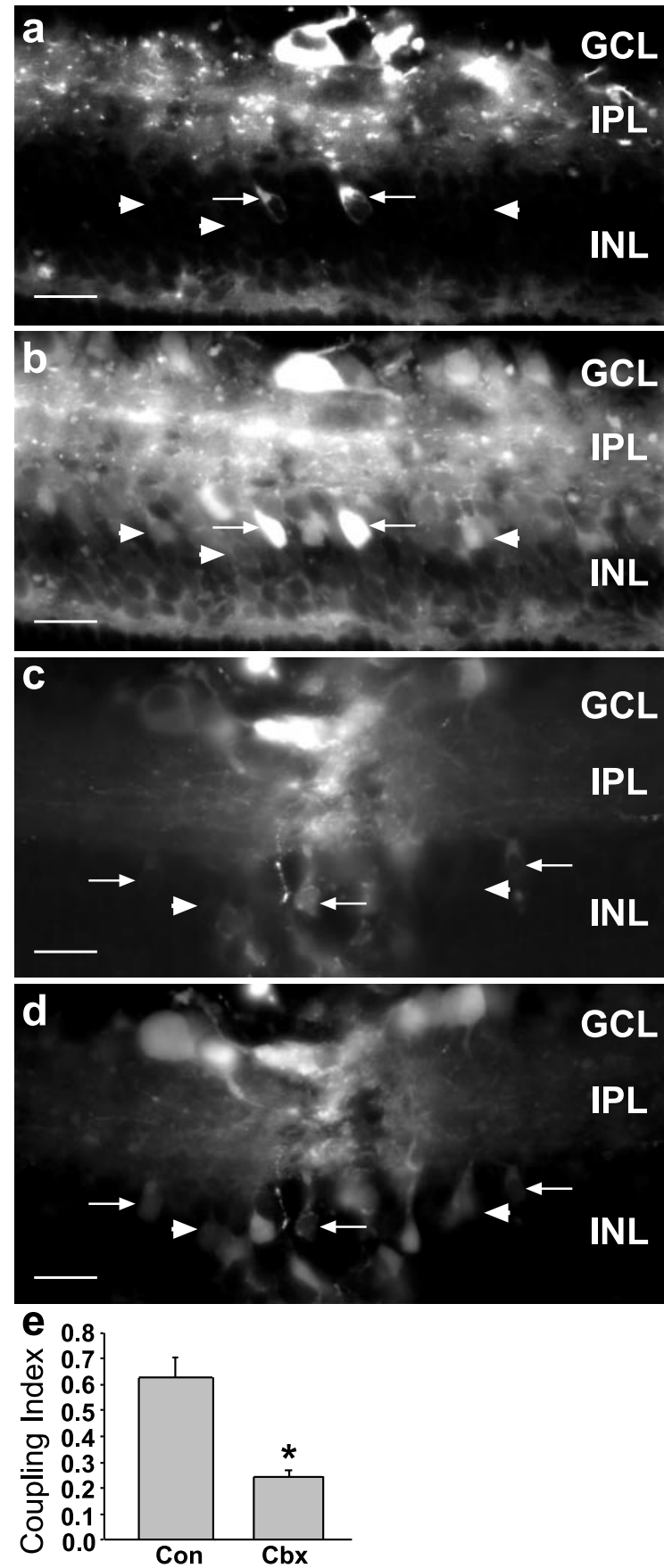

Figure 5. Carbenoxolone decreased dye coupling in the scrape-loading model. Shown is control P13 rat retina scrape-loaded with RD ( $a$ ) and Neurobiotin $(b)$, which was visualized with Cy2-streptavidin. In $a$ and $b$ note that many Neurobiotin-labeled cells were not labeled with RD (arrowheads), indicating that they were coupled to the scrape-loaded cells (arrows). c, d, P13 retina treated with carbenoxolone $(20 \mathrm{mg} / \mathrm{kg}$, s.c., followed by $10 \mu \mathrm{m})$, scrape-loaded with RD and Neurobiotin. $d$, Neurobiotin labeling of same field as in $c$; only occasional cells were single labeled for Neurobiotin (arrowheads), indicating decreased coupling as compared with control $(a, b)$. The same concentration of carbenoxolone that decreased bystander cell killing inhibited coupling to similar levels. Scale bars in $a-d, 20 \mu \mathrm{m}$. e, The Coupling Index for retinas treated with carbenoxolone demonstrates that this gap junction inhibitor decreased the Coupling Index significantly as compared with control (asterisk indicates group significantly different from control; two-tailed $t$ test, $p<0.01)$. Con, Control; Cbx, carbenoxolone.

uct of the cell death pathway passed into coupled cells and induced caspase activation. The fact that the dying cells were dyecoupled clearly demonstrates that gap junctions participate in bystander killing. Our efficacy at killing cells by $\mathrm{C} c$ injection was
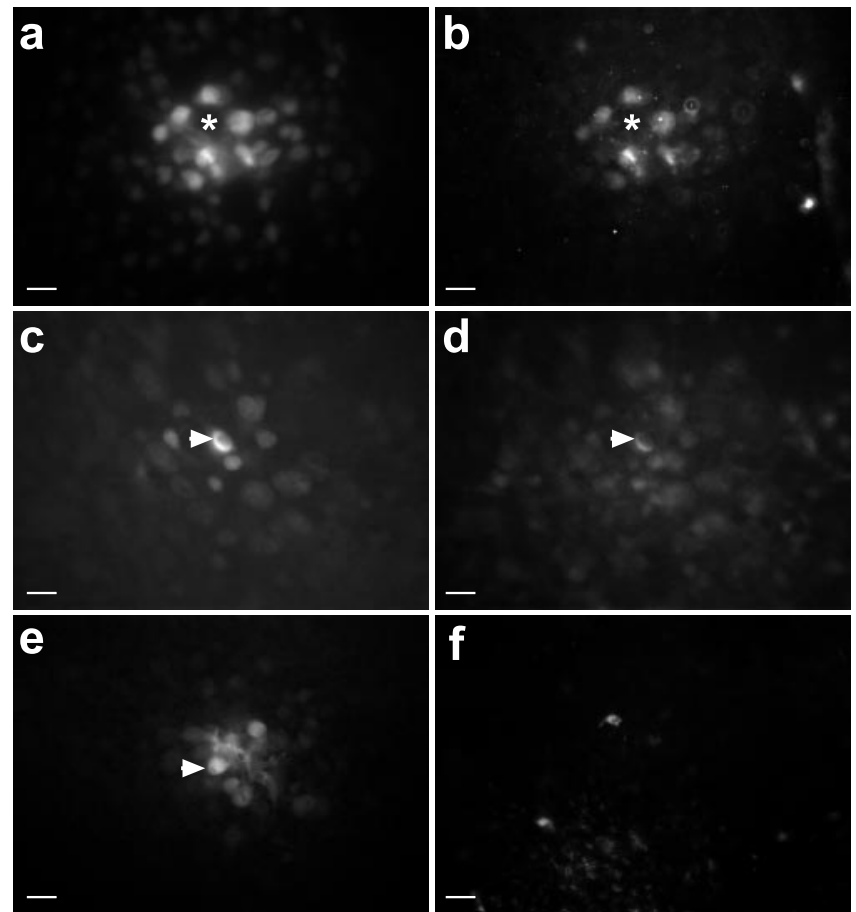

Figure 6. Dying bystander cells were coupled via gap junctions to primary cells. $a-d$, Singlecell injections of AF488 (a gap junction-permeable dye) and Cc in the GCL showed that multiple coupled cells were immunolabeled for cleaved caspase-3. a, AF488 labeled cells coupled to the injected cell. Asterisks show location of injected cell that was no longer present $1 \mathrm{hr}$ after the injection; presumably, it died and detached or was cleared by engulfment. $b$, Cleaved caspase-3 labeled many of the coupled cells in $a . c, d$, AF488 ( $c$ ) and cleaved caspase-3 (d) labeling showed that the injected cell (arrowhead) and other coupled cells were immunopositive. $e$, $f$, Control injections of AF488 (e) into a single cell (arrowhead) did not induce caspase-3 cleavage $(f)$ in the injected or coupled cells. Scale bars in $a-f, 20 \mu \mathrm{m}$.

much lower than by scrape-loading, suggesting that the concentration of $\mathrm{C} c$ necessary to induce cell death is achieved more readily by scrape-loading than by injection. It has been reported recently that $\mathrm{C} c$ injection of isolated nerve growth factor (NGF)dependent neurons yields very low levels of cell death, with NGF protecting cells from the downstream effects of cytoplasmic $\mathrm{Cc}$ (Deshmukh and Johnson, 1998; Deshmukh et al., 2002). It is not clear whether retinal cells also have a neurotrophin-dependent protection against low levels of cytoplasmic $\mathrm{C} c$; however, we did observe little cell death in horizontal cells scrape-loaded with $\mathrm{Cc}$ (Fig. $4 a, b$ ), a cell type that has been shown to be dependent on autocrine NGF (Karlsson et al., 2001).

Other possible mechanisms may contribute to the tendency of cells to die near to one another in both space and time. Extracellular signals such as withdrawal of trophic support may impact multiple cells simultaneously, the bystander cells may depend directly on the primarily dying cells for their survival, or dying cells may release substances into their immediate environment that initiate apoptosis in surrounding cells. Although the extent to which these extracellular signaling mechanisms directly operate in the bystander effect or act via the regulation of cell coupling is not known, it is clear that gap junctions play an important role in this process.

It has been theorized recently that gap junction-mediated cell killing may provide a mechanism of cone photoreceptor cell death secondary to the loss of rod photoreceptors in degenerative diseases caused by mutation of rod-specific genes (Ripps, 2002). However, this intriguing possibility remains to be tested experi- 
mentally. Although the present study does not address the intercellular spread of cell death in photoreceptors directly, it suggests that gap junction-mediated bystander cell killing may have important consequences in degenerative diseases or traumatic injuries to the retina.

\section{References}

Becker DL, Bonness V, Catsicas M, Mobbs P (2002) Changing patterns of ganglion cell coupling and connexin expression during chick retinal development. J Neurobiol 15:280-293.

Brustugun OT, Fladmark KE, Doskeland SO, Orrenius S, Zhivotovsky B (1998) Apoptosis induced by microinjection of cytochrome $c$ is caspasedependent and is inhibited by Bcl-2. Cell Death Differ 5:660-668.

Chang GQ, Hao Y, Wong F (1993) Apoptosis: final common pathway of photoreceptor death in $\mathrm{rd}$, rds, and rhodopsin mutant mice. Neuron 11:595-605.

Cook B, Lewis GP, Fisher SK, Adler R (1995) Apoptotic photoreceptor degeneration in experimental retinal detachment. Invest Ophthalmol Vis Sci 36:990-996.

Cook B, Portera-Cailliau C, Adler R (1998) Developmental neuronal death is not a universal phenomenon among cell types in the chick embryo retina. J Comp Neurol 396:12-19.

Coucouvanis E, Martin GR (1995) Signals for death and survival: a two step mechanism for cavitation in the vertebrate embryo. Cell 83:279-287.

Cusato K, Stagg SB, Reese BE (2001) Two phases of increased cell death in the inner retina following early elimination of the ganglion cell population. J Comp Neurol 439:440-449.

Davidson JS, Baumgarten IM (1988) Glycyrrhetinic acid derivatives: a novel class of inhibitors of gap-junctional intercellular communication. Structure-activity relationships. J Pharmacol Exp Ther 246:1104-1107.

De Pina-Benabou MH, Srinivas M, Spray DC, Scemes E (2001) Calmodulin kinase pathway mediates the $\mathrm{K}^{+}$-induced increase in gap junctional communication between mouse spinal cord astrocytes. J Neurosci 21:6635-6643.

Dermietzel R, Kremer M, Paputsoglu G, Stang A, Skerrett IM, Gomes D, Srinivas M, Janssen-Bienhold U, Weiler R, Nicholson BJ, Bruzzone R, Spray DC (2000) Molecular and functional diversity of neural connexins in the retina. J Neurosci 20:8331-8343.

Deshmukh M, Johnson Jr EM (1998) Evidence of a novel event during neuronal death: development of competence-to-die in response to cytoplasmic cytochrome $c$. Neuron 21:695-705.

Deshmukh M, Du C, Wang X, Johnson Jr EM (2002) Exogenous Smac induces competence and permits caspase activation in sympathetic neurons. J Neurosci 22:8018-8027.

De Vries SH, Qi X, Smith R, Makous W, Sterling P (2002) Electrical coupling between mammalian cones. Curr Biol 12:1900-1907.

El-Fouly MH, Trosko JE, Chang CC (1987) Scrape-loading and dye transfer. A rapid and simple technique to study gap junctional intercellular communication. Exp Cell Res 168:422-430.

Elshami AA, Saavedra A, Zhang H, Kucharczuk JC, Spray DC, Fishman GI, Amin KM, Kaiser LR, Albelda SM (1996) Gap junctions play a role in the "bystander effect" of the herpes simplex thymidine kinase/ganciclovir system in vitro. Gene Ther 3:85-92.

Gavrieli Y, Sherman Y, Ben-Sasson SA (1992) Identification of programmed cell death in situ via specific labeling of nuclear DNA fragmentation. J Cell Biol 119:493-501.

Georges P, Madigan MC, Provis JM (1999) Apoptosis during development of the human retina: relationship to foveal development and retinal synaptogenesis. J Comp Neurol 413:198-208.

Glucksman A (1951) Cell death in normal vertebrate ontogeny. In: Biological reviews of the Cambridge philosophical society (Fox HM, ed), pp 59-86. Cambridge, UK: Cambridge UP.

Graham A, Koentges G, Lumsden A (1996) Neural crest apoptosis and the establishment of craniofacial pattern: an honorable death. Mol Cell Neurosci 8:76-83.

Horsburgh GM, Sefton AJ (1987) Cellular degeneration and synaptogenesis in the developing retina of the rat. J Comp Neurol 263:553-566.

Johnson PT, Williams RR, Cusato K, Reese BE (1999) Rods and cones project to the inner plexiform layer during development. J Comp Neurol 414:1-12.
Jomary C, Neal MJ, Jones SE (2001) Characterization of cell death pathways in murine retinal neurodegeneration implicates cytochrome $c$ release, caspase activation, and bid cleavage. Mol Cell Neurosci 18:335-346.

Karlsson M, Mayordomo R, Reichardt LF, Catsicas S, Karten HJ, Hallböök F (2001) Nerve growth factor is expressed by postmitotic avian retinal horizontal cells and supports their survival during development in an autocrine mode of action. Development 128:471-479.

Kerr JF, Wyllie AH, Currie AR (1972) Apoptosis: a basic biological phenomenon with wide-ranging implications in tissue kinetics. Br J Cancer 26:239-257.

Kita H, Armstrong W (1991) A biotin-containing compound $\mathrm{N}$-(2aminoethyl)biotinamide for intracellular labeling and neuronal tracing studies: comparison with biocytin. J Neurosci Methods 37:141-150.

Li J, Billiar TR, Talanian RV, Kim YM (1997) Nitric oxide reversibly inhibits seven members of the caspase family via $S$-nitrosylation. Biochem Biophys Res Commun 240:419-424.

Li P, Nijhawan D, Budihardjo I, Srinivasula SM, Ahmad M, Alnemri ES, Wang X (1997) Cytochrome $c$ and dATP-dependent formation of APAF-1/caspase-9 complex initiates an apoptotic protease cascade. Cell 91:479-489.

Lin JH-C, Weigel H, Cotrina ML, Liu S, Bueno E, Hansen AJ, Hansen TW, Goldman S, Nedergaard M (1998) Gap junction-mediated propagation and amplification of cell injury. Nat Neurosci 1:494-500.

Linden R (2000) The anti-death league: associative control of apoptosis in developing retinal tissue. Brain Res Rev 32:146-158.

Linseman DA, Heidenreich KA, Fisher SK (2001) Stimulation of $\mathrm{M}_{3}$ muscarinic receptors induces phosphorylation of the $\mathrm{Cdc} 42$ effector activated $\mathrm{Cdc} 42 \mathrm{Hs}$-associated kinase-1 via a Fyn tyrosine kinase signaling pathway. J Biol Chem 276:5622-5628.

Liu X, Kim CN, Yang J, Jemmerson R, Wang X (1996) Induction of apoptotic program in cell free extracts: requirement for dATP and cytochrome $c$. Cell 86:147-157.

McMahon DG, Knapp AG, Dowling JE (1989) Horizontal cell gap junctions: single-channel conductance and modulation by dopamine. Proc Natl Acad Sci USA 86:7639-7643.

McNeil PL, Murphy RF, Lanni F, Taylor DL (1984) A method for incorporating macromolecules into adherent cells. J Cell Biol 98:1556-1564.

Menezes JRL, Froes M, Moura Neto V, Lent R (2000) Gap junctionmediated coupling in the postnatal anterior subventricular zone. Dev Neurosci 22:34-43.

Mesnil M, Piccoli C, Tiraby G, Willecke K, Yamasaki H (1996) Bystander killing of cancer cells by herpes simplex virus thymidine kinase gene is mediated by connexins. Proc Natl Acad Sci USA 93:1831-1835.

Milán M, Campuzano S, García-Bellido A (1997) Developmental parameters of cell death in the wing disc of Drosophila. Proc Natl Acad Sci USA 94:5691-5696.

Mills SL, Massey SC (1995) Differential properties of two gap junctional pathways made by AII amacrine cells. Nature 377:734-737.

Moro MA, Russel RJ, Cellek S, Lizasoain I, Su Y, Darley-Usmar VM, Radomski MW, Moncada S (1996) cGMP mediates the vascular and platelet actions of nitric oxide: confirmation using an inhibitor of the soluble guanylyl cyclase. Proc Natl Acad Sci USA 93:1480-1485.

Morris JD, Price B, Lloyd AC, Self AJ, Marshall CJ, Hall A (1989) Scrapeloading of Swiss $3 \mathrm{~T} 3$ cells with ras protein rapidly activates protein kinase $\mathrm{C}$ in the absence of phosphoinositide hydrolysis. Oncogene 4:27-31.

Nicholson DW, Ali A, Thornberry NA, Vaillancourt JP, Ding CK, Gallant M, Gareau Y, Griffin PR, Labelle M, Lazebnik YA (1995) Identification and inhibition of the ICE/CED-3 protease necessary for mammalian apoptosis. Nature 376:37-43.

Ortiz D, Baldwin MM, Lucas JJ (1987) Transient correction of genetic defects in cultured animal cells by introduction of functional proteins. Mol Cell Biol 7:3012-3017.

Penn AA, Wong ROL, Shatz CJ (1994) Neuronal coupling in the developing mammalian retina. J Neurosci 14:3805-3815.

Perry VH, Henderson R, Linden R (1983) Postnatal changes in retinal ganglion cell and optic axon populations in the pigmented rat. J Comp Neurol 219:356-368.

Rauz S, Walker EA, Shackleton CH, Hewison M, Murray PI, Stewart PM (2001) Expression and putative role of $11 \beta$-hydroxysteroid dehydrogenase isozymes within the human eye. Invest Ophthalmol Vis Sci 42:20372042. 
Raviola E, Raviola G (1982) Structure of the synaptic membranes in the inner plexiform layer of the retina: a freeze fracture study in monkeys and rabbits. J Comp Neurol 209:233-248.

Ripps H (2002) Cell death in retinitis pigmentosa: gap junctions and the "bystander" effect. Exp Eye Res 74:327-336.

Rozental R, Srinivas M, Spray DC (2001) How to close a gap junction channel. Methods Mol Biol 154:447-476.

Simpson I, Rose B, Loewenstein WR (1977) Size limits of molecules permeating the junctional membrane channels. Science 195:294-296.

Singh RJ, Hogg N, Joseph J, Kalyanaraman B (1996) Mechanism of nitric oxide release from S-nitrosothiols. J Biol Chem 271:18596-18603.

Spray DC, Ginzberg RD, Morales EA, Gatmaitan Z, Arias IM (1986) Electrophysiological properties of gap junctions between dissociated pairs of rat hepatocytes. J Cell Biol 103:135-144.

Trosko JE, Goodman JI (1994) Intercellular communication may facilitate apoptosis: implications for tumor production. Mol Carcinog 11:8-12.

Vaney DI (1991) Many diverse types of retinal neurons show tracer coupling when injected with biocytin or Neurobiotin. Neurosci Lett 125:187-190.

Vapaatalo H, Linden IB, Metsa-Ketela T, Kangasaho M, Laustiola K (1978)
Effect of carbenoxolone on phosphodiesterases and prostaglandin synthetase activities. Experientia 34:384-385.

Vile RG, Hart IR (1993) Use of tissue-specific expression of the herpes simplex virus thymidine kinase gene to inhibit growth of established murine melanomas following direct intratumoral injection of DNA. Cancer Res 53:3860-3864.

Voyvodic JT, Burne JF, Raff MC (1995) Quantification of normal cell death in the rat retina: implications for clone composition in cell lineage analysis. Eur J Neurosci 7:2469-2478.

Vrionis FD, Wu JK, Qi P, Waltzman M, Cherington V, Spray DC (1997) The bystander effect exerted by tumor cells expressing the herpes simplex virus thymidine kinase (HSVtk) gene is dependent on connexin expression and cell communication via gap junctions. Gene Ther 4:577-585.

Wässle H, Reimann HJ (1978) The mosaic of nerve cells in the mammalian retina. Proc R Soc Lond [Biol] 200:441-461.

Wilson MR, Close TW, Trosko JE (2000) Cell population dynamics (apoptosis, mitosis, and cell-cell communication) during disruption of homeostasis. Exp Cell Res 254:257-268.

Young R (1984) Cell death during the differentiation of the retina in mouse. J Comp Neurol 229:362-373. 